\title{
Strengthening laboratory capacity for detection of respiratory viral pathogens through the Global Health Security Agenda (GHSA) framework
}

\begin{tabular}{|c|c|}
\hline $\begin{array}{l}\text { Authors: } \\
\text { Brett Whitake } \\
\text { Karen A. Alroy } \\
\text { Erica Guthrie }^{2} \\
\text { Sarah Schildec } \\
\text { Susan Hiers }{ }^{3} \\
\text { Jill Woodard } \\
\text { S. Arunmozhi }\end{array}$ & $\begin{array}{l}{ }^{1} \text { (1) } \\
\operatorname{ker}^{2} \text { (1) } \\
\text { (1) } \\
\text { Balajee } \\
\end{array}$ \\
\hline \multicolumn{2}{|c|}{$\begin{array}{l}\text { Affiliations: } \\
{ }^{1} \text { Division of Viral Diseases, } \\
\text { National Center for } \\
\text { Immunization and } \\
\text { Respiratory Diseases, } \\
\text { Centers for Disease Control } \\
\text { and Prevention, Atlanta, } \\
\text { Georgia, United States }\end{array}$} \\
\hline \multicolumn{2}{|c|}{$\begin{array}{l}{ }^{2} \text { Influenza Division, National } \\
\text { Center for Immunization } \\
\text { and Respiratory Diseases, } \\
\text { Centers for Disease Control } \\
\text { and Prevention, Atlanta, } \\
\text { Georgia, United States }\end{array}$} \\
\hline \multicolumn{2}{|c|}{$\begin{array}{l}{ }^{3} \text { Office of the Director, } \\
\text { National Center for } \\
\text { Immunization and } \\
\text { Respiratory Diseases, } \\
\text { Centers for Disease Control } \\
\text { and Prevention, Atlanta, } \\
\text { Georgia, United States }\end{array}$} \\
\hline \multicolumn{2}{|c|}{$\begin{array}{l}\text { Corresponding author: } \\
\text { S. Arunmozhi Balajee, } \\
\text { fir3@cdc.gov }\end{array}$} \\
\hline \multicolumn{2}{|c|}{$\begin{array}{l}\text { Received: } 10 \text { July } 2018 \\
\text { Accepted: } 17 \text { Jan. } 2019 \\
\text { Published: } 18 \text { July } 2019\end{array}$} \\
\hline \multicolumn{2}{|c|}{$\begin{array}{l}\text { How to cite this article: } \\
\text { Whitaker B, Alroy KA, } \\
\text { Guthrie E, et al. } \\
\text { Strengthening laboratory } \\
\text { capacity for detection of } \\
\text { respiratory viral pathogens } \\
\text { through the Global Health } \\
\text { Security Agenda (GHSA) } \\
\text { framework. Afr J Lab Med. } \\
\text { 2019;8(1), a861. https://doi. } \\
\text { org/10.4102/ajlm.v8i1.861 }\end{array}$} \\
\hline \multicolumn{2}{|l|}{ Read online: } \\
\hline 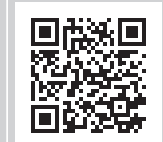 & $\begin{array}{l}\text { Scan this QR } \\
\text { code with your } \\
\text { smart phone or } \\
\text { mobile device } \\
\text { to read online. }\end{array}$ \\
\hline
\end{tabular}

Background: Endemic and emerging respiratory viruses are a threat to public health, and a robust public health laboratory system is essential to ensure global health security.

Objective: This program sought to expand molecular laboratory testing capacity to detect a broad range of respiratory pathogens in clinical respiratory specimens collected during disease surveillance and outbreak investigations.

Methods: As a part of the Global Health Security Agenda (GHSA), the United States Centers for Disease Control and Prevention utilised the equipment and training infrastructure already in place at the World Health Organization National Influenza Centers to expand testing capacity for respiratory viruses in laboratories in GHSA partner countries. This was done through the provision of quality assured reagents, including multiplex platforms and technical guidance for laboratory staff, as well as the assessment of laboratory testing accuracy.

Conclusion: Early findings illustrated that GHSA laboratories have been able to expand testing capacity using specimens from routine surveillance, as well as from outbreak situations.

Keywords: public health laboratory; multiplex; respiratory viruses; global health security; polymerase chain reaction.

\section{Introduction}

Acute respiratory infections have threatened public health for decades. ${ }^{1,2,3,4}$ In 2003, when severe acute respiratory syndrome emerged out of Hong Kong, it illustrated the speed with which respiratory pathogens could spread globally as well as their potential for worldwide economic impact. $^{5}$ Two respiratory viruses have recently emerged as public health threats: influenza A/H7N9 and Middle East respiratory syndrome coronavirus. ${ }^{6,7}$ According to the International Health Regulations established by the World Health Organization (WHO), countries should develop capacities for timely detection and rapid public health response to emerging and re-emerging threats, and these capacities rely in part on a robust public health laboratory system. ${ }^{8}$

The Global Health Security Agenda (GHSA) (www.ghsagenda.org) is a partnership of countries and international organisations launched in 2014 to strengthen global capacity to detect, prevent and respond to disease threats that occur naturally, accidentally or deliberately. One of GHSA's primary areas of focus, known as an 'action package', is an emphasis on strengthening national laboratory systems (Action Package: Detect 1). ${ }^{9}$ Through this action package, GHSA enables countries to enhance real-time bio-surveillance and ensure that laboratories are capable of safe, accurate detection and characterisation of epidemic-prone pathogens, including both known and novel threats. ${ }^{9}$ In order for public health laboratories to prepare for outbreaks and emerging pandemic threats, they should demonstrate ongoing capacities for routine diagnostics.

For almost a decade, the United States Centers for Disease Control and Prevention (CDC) Influenza Division has developed laboratory capacity for seasonal influenza virus and pandemic influenza preparedness. As a WHO collaborating center, CDC provides technical assistance for influenza testing in a network of global laboratories, known as National Influenza Centers (NICs), which have functional links to their assigned WHO reference laboratory and access to quality assured reagents from the CDC Influenza Division through the International Reagent Resource (IRR) (https:/ / www.internationalreagentresource.org). The NICs often have standardised, stateof-the-art equipment, in addition to well-trained molecular biologists. Specimens for routine 
testing at NICs are received from influenza surveillance sites that include regional hospitals and clinics using the severe acute respiratory infection (SARI) or influenza-like illness case definitions. Frequently, SARI and influenza-like illness sentinel systems are models of successful surveillance in resource-limited countries where epidemiologic data are linked to specimen collection and laboratory testing. ${ }^{10}$ An opportunity exists to expand the existing surveillance systems at NICs in GHSA countries by expanding testing capacity for other priority agents.

Accordingly, as a part of the GHSA, the United States CDC strengthened and expanded its existing capacity to test for respiratory viral pathogens in laboratories of select countries (Table 1). These activities, detailed below, can serve as a model for other countries with NICs and laboratories with moderate technical capabilities that are looking to expand their capacities beyond influenza.

\section{Reagents for testing}

In order to expand its laboratory capacity to test for respiratory viruses beyond influenza, CDC's Division of Viral Diseases deployed a panel of in-house singleplex realtime reverse transcriptase polymerase chain reaction (rRTPCR) assays (Table 2). ${ }^{11,12,13,14,15}$ Specifically, a subset of seven CDC in-house singleplex rRT-PCR assays and one specimen quality control assay RNase P (RNP) was distributed as a kit for SARI surveillance and outbreak investigations. All CDC in-house assays utilise Taqman ${ }^{\circledR}$ probes (Applied Biosystems, Foster City, California, United States) with a 5' FAM fluorophore and either an internally linked BHQ-1 ${ }^{\circledR}$ (Biosearch Technologies, Novato, California, United States) or $3^{\prime}$ terminal BHQ- ${ }^{\circledR}$ (Biosearch Technologies, Novato, California, United States) quencher. The RNP control allows laboratory scientists to know if the quality of nucleic acid has been compromised, potentially confounding any rRT-PCR results. These assays have been previously validated to work with several commercial one-step rRT-PCR enzyme kits such as the AgPath-ID ${ }^{\mathrm{TM}}$ One-Step RT-PCR kit (Thermo Fisher, Waltham, Massachusetts, United States) and the qScript $^{\circledR}$ One-Step qRT-PCR kit, low ROX (Quantabio, Beverly, Massachusetts, United States). Real-time PCR instruments evaluated by CDC to be compatible with this reagent panel include the 7500 Fast Dx $^{\mathrm{TM}}$ (Applied Biosystems, Foster City, California, United States), Mx3000P ${ }^{\circledR}$ and Mx3005P ${ }^{\circledR}$ (Agilent, Santa Clara, California, United States), CFX96 ${ }^{\mathrm{TM}}$ and CFX96 ${ }^{\mathrm{TM}}$ Touch (Bio-Rad, Hercules, California, United States), and the Viia ${ }^{\mathrm{TM}} 7$ in both TaqMan ${ }^{\mathrm{TM}}$ Array Card and 96-well PCR plate formats (Thermo Fisher, Waltham, Massachusetts, United States). ${ }^{11,12,13,14,15,16}$

When encountering an outbreak of unknown etiology, a multiplex platform may enable laboratories to rapidly identify the potential pathogen causing illness; therefore, CDC provided countries access to a multiplex assay kit known as FTD33 Respiratory Pathogens ${ }^{\circledR}$ (Fast-track Diagnostics, Esch-surAlzette, Luxembourg), a commercially available multiplex assay that can detect up to 33 common respiratory viruses and bacteria. The FTD33 comes with its own proprietary primers, probes, PCR buffer, enzyme mix and controls needed to perform the tests. A previous version of the FTD33 kit, the FTD21 Respiratory Pathogens Kit, was validated against the CDC respiratory virus singleplex assay panel. ${ }^{17}$ Table 2 compares the pathogens targeted with the CDC sevenpathogen non-influenza respiratory virus panel and the FTD33.

\section{Ethical considerations}

This article followed all ethical standards for a research without direct contact with human or animal subjects.

TABLE 1: Countries with expanded non-influenza virus reagent access that engaged in strengthening activities (February 2016-September 2017).

\begin{tabular}{|c|c|c|c|c|}
\hline Country & $\begin{array}{l}\text { No. of laboratories granted } \\
\text { IRR access }\end{array}$ & No. of NIC laboratories & $\begin{array}{l}\text { Total non-influenza respiratory } \\
\text { virus products received from IRR }\end{array}$ & $\begin{array}{l}\text { Participation date in basic } \\
\text { training on respiratory viruses }\end{array}$ \\
\hline Bangladesh & 2 & 1 & 94 & July 2016 \\
\hline Benin & 0 & 0 & 0 & April 2017 \\
\hline Burkina Faso & 1 & 0 & 23 & July 2016 \\
\hline Cameroon & 1 & 1 & 37 & July 2016 \\
\hline Côte D'Ivoire & 1 & 1 & 28 & July 2016 \\
\hline Democratic Republic of Congo & 1 & 0 & 29 & April 2017 \\
\hline Ethiopia & 1 & 0 & 20 & - \\
\hline Gambia & 1 & 0 & 30 & - \\
\hline Ghana & 1 & 1 & 14 & - \\
\hline Guinea-Bissau & 0 & 0 & 0 & April 2017 \\
\hline India & 2 & 1 & 20 & - \\
\hline Indonesia & 1 & 1 & 4 & - \\
\hline Kenya & 2 & 1 & 67 & - \\
\hline Mauritania & 1 & 0 & 7 & April 2017 \\
\hline Pakistan & 1 & 1 & 9 & July 2016 \\
\hline Senegal & 1 & 1 & 18 & July 2016 \\
\hline Tanzania & 1 & 1 & 14 & July 2016 \\
\hline Togo & 1 & 0 & 13 & April 2017 \\
\hline Uganda & 1 & 1 & 1 & July 2016 \\
\hline Vietnam & 4 & 2 & 72 & July 2016 \\
\hline
\end{tabular}

IRR, International Reagents Resource; NIC, National Influenza Center. 
TABLE 2: Human respiratory pathogens targeted by Centers for Disease Control and Prevention assays and fast-track diagnostics respiratory pathogens panel.

\begin{tabular}{|c|c|}
\hline $\begin{array}{l}\text { CDC non-influenza respiratory virus } \\
\text { assays }\end{array}$ & FTD33 assays \\
\hline Respiratory syncytial virus (RSV) $\dagger$ & Respiratory syncytial virus (HRSVA \& B) \\
\hline Human metapneumovirus (hMPV) $\dagger$ & Human metapneumovirus (HMPVA \& B) \\
\hline Human rhinovirus $(\mathrm{hRV}) \dagger$ & Human rhinovirus (RV) \\
\hline Human adenovirus (hAdv) $\dagger$ & Human adenovirus (HAdV) \\
\hline Parainfluenza 1 (hPIV1) $\dagger$ & Human parainfluenza 1 (HPIV1) \\
\hline Human parainfluenza 2 (hPIV2) $\dagger$ & Human parainfluenza 2 (HPIV2) \\
\hline Human parainfluenza 3 (hPIV3) $\dagger$ & Human parainfluenza 3 (HPIV3) \\
\hline RNase $P(R N P) \dagger$ & Human parainfluenza 4 (HPIV4) \\
\hline Human parainfluenza 4 (hPIV4) & $\begin{array}{l}\text { Influenza A, B, C, H1N1 (FLUA, FLUB, } \\
\text { FLUC, H1N1) }\end{array}$ \\
\hline $\begin{array}{l}\text { Human coronaviruses 229E, OC43, NL63, } \\
\text { HKU1 }\end{array}$ & $\begin{array}{l}\text { Human coronavirus (Cor63, Cor229, } \\
\text { Cor43, HKU) }\end{array}$ \\
\hline \multirow[t]{15}{*}{ MERS-CoV assays upE, N2, and N3 } & Human bocavirus (HBoV) \\
\hline & Enterovirus (EV) \\
\hline & Human parechovirus (HPeV) \\
\hline & Mycoplasma pneumoniae (Mpneu) \\
\hline & Staphylococcus aureus (Saur) \\
\hline & Streptococcus pneumoniae (Spneu) \\
\hline & Klebsiella pneumoniae (Kpneu) \\
\hline & Moraxella catarrhalis (Morax) \\
\hline & $\begin{array}{l}\text { Haemophilus influenza/b (Haeinf/ } \\
\text { Haeinfb) }\end{array}$ \\
\hline & Legionella (Legio) \\
\hline & Pneumocystis jiroveci (PCP) \\
\hline & Bordetella pertussis (Bord) \\
\hline & Salmonella species (Salm) \\
\hline & Chlamydia pneumoniae (Cpneu) \\
\hline & IC(EAV) - internal control \\
\hline
\end{tabular}

Note: Abbreviations in parentheses are shorthand assay names taken from the respective protocols/manuals for the pathogen targets listed.

CDC, Centers for Disease Control and Prevention; FTD, Fast-track Diagnostics.

$\dagger$, Assays part of the CDC non-influenza respiratory virus real-time RT-PCR assay panel, for SARI surveillance/outbreaks.

\section{Reagent procurement}

Quality assured reagents are essential for accuracy in diagnostic testing. In addition, a reliable method for procurement and distribution of available reagents is necessary to order and receive laboratory materials, particularly when many of the reagents are temperature sensitive. Utilising GHSA funds, the online reagent portal, the IRR, was expanded to include 14 new custom products including the FTD33 kit, the CDC-developed respiratory virus rRT-PCR assay kits and controls, as well as ancillary commercial products such as rRT-PCR enzyme kits and specimen extraction kits required to run the $\mathrm{CDC}$ respiratory virus rRT-PCR assays. The IRR is a programme established by $C D C$ to provide registered users with various reagents and information for the study and detection of influenza virus. It was chosen as the delivery mechanism for these reagents, because the selected laboratories for GHSA were already using or in the process of being approved to use the IRR for the purpose of WHO influenza surveillance, eliminating the need to establish a new or duplicative reagent distribution plan.

\section{Training workshops}

In addition to enhancing laboratory capacity through the availability of quality reagents, CDC has enhanced its technical capacity through partnerships to conduct workforce training. Working with the Association of Public Health Laboratories, laboratory training took place in Atlanta in July of 2016. Nine countries participated and were trained in the expanded respiratory viral pathogen detection, including Bangladesh, Burkina Faso, Cameroon, Côte d'Ivoire, Pakistan, Senegal, Uganda, Tanzania and Vietnam. The Pasteur Institute of Paris, France, conducted similar laboratory training in Yaoundé, Cameroon, in April 2017 with representatives from Benin, Guinea-Bissau, Mali, Mauritania, the Democratic Republic of Congo and Togo. Table 1 lists countries that have received training up to December 2017.

The training curriculum included lectures from subject matter experts and hands-on laboratory exercises in order to familiarise attendees with the CDC rRT-PCR assays and the use of the FTD33. Didactic lectures covered a range of topics including an overview of respiratory viruses, quality assurance and biosafety guidelines, setting up a molecular diagnostics laboratory, and performing rRT-PCR assays on human clinical respiratory specimens. The hands-on exercises covered total nucleic acid isolation from clinical respiratory specimens, setting up rRT-PCR reactions for CDC singleplex and FTD33 multiplex assays, as well as analysis of the rRTPCR data. Laboratory subject matter experts from CDC and the Association of Public Health Laboratories guided participants through the exercises ensuring everyone followed proper techniques. The specimens used for training were mock respiratory specimens spiked with inactivated respiratory viruses. By pre-characterising these specimens with the CDC respiratory virus panel, the participants' results could be used as a metric for successful learning.

\section{Quality assessment}

In order to test each country's laboratory capabilities and availability of reagents following the training, CDC is preparing to provide laboratories with external quality assessment panels. These panels, produced by Quality Control for Molecular Diagnostics (http:/ /www.qcmd.org), enable laboratories to process and test proficiency samples using the same protocol they use for clinical specimens. The results will be reported back to Quality Control for Molecular Diagnostics for scoring and the compilation of performance reports. Confidential individual reports will be returned to the respective laboratories. Based on their individual performances, CDC may recommend additional training and technical support, if necessary. For laboratories expanding their viral testing capacity, the availability of external quality assessment panels ensures quality performance.

\section{Preliminary summary data of expansion capacity}

From February 2016 to September 2017, the IRR shipped 502 individual products, supporting respiratory virus rRT-PCR testing, to 25 different laboratories in 19 countries, and 
scientists from 15 countries received training (Table 1). Preliminary data from two of these laboratories indicated that a total of 362 respiratory specimens were tested, 158 by CDC singleplex respiratory virus assays and 204 by the FTD33 multiplex assay. It is hoped that in the future, the public health laboratory workforce in GHSA countries will collaborate with their epidemiology counterparts and utilise these reagents for the purposes of understanding the diversity of circulating respiratory viral pathogens, calculating the burden of disease for priority pathogens, and using multiplex platforms for outbreak detection.

\section{Next steps and conclusion}

The GHSA measures its success according to metrics defined by the WHO's Joint External Evaluation tool. ${ }^{18}$ In the arena of national laboratory systems, two of these indicators include the capacity for the detection of priority diseases, as well as for effective and modern diagnostics. The training and materials provided through CDC's engagement in GHSA laboratory strengthening has provided tools and building blocks to more than one-third of all GHSA countries to more readily achieve their goals in laboratory capacity. Data generated from expanded testing will allow for a more complete understanding of the burden of disease in their country. A routine system of collection, transportation, testing and results sharing in a quality assured environment will enable the public health system to respond to outbreaks when they occur.

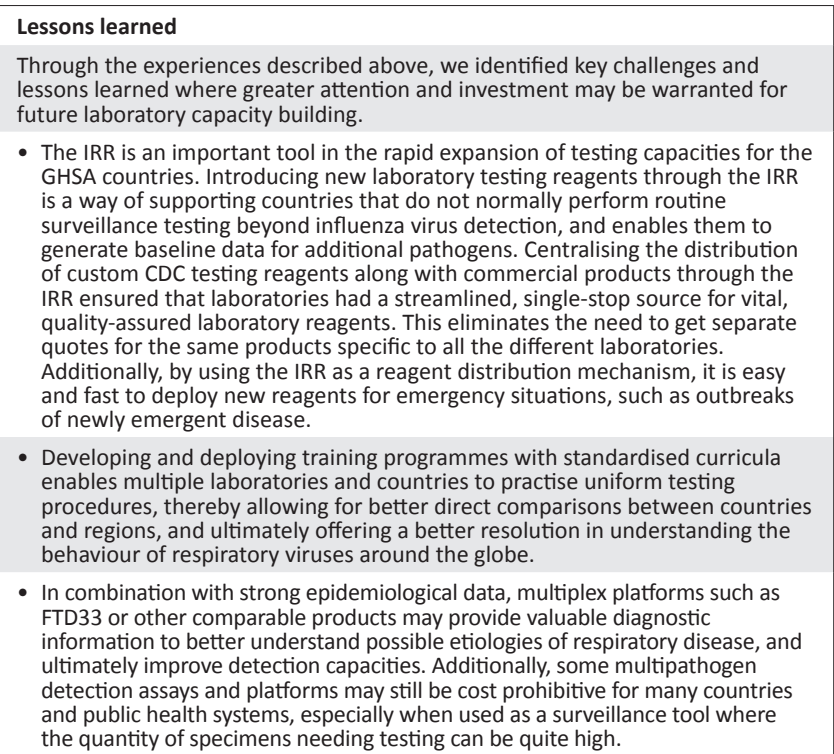

\section{Acknowledgements} Competing interests

The authors declare that they have no financial or personal relationships that may have inappropriately influenced them in writing this article.

\section{Authors' contributions}

B.W. and S.A.B. provided the article framework. K.A.A., E.G., S.S., S.H. and J.W. added clarifications and additional text where appropriate based on their involvement and expertise.

\section{Source of support}

None.

\section{Data availability statement}

Data sharing is not applicable to this article as no new data were created or analysed in this study.

\section{Disclaimer}

The findings and conclusions in this report are those of the authors and do not necessarily represent the official position of the Centers for Disease Control and Prevention.

\section{References}

1. Cox N, Subbarao K. Global epidemiology of influenza: Past and present. Annu Rev Med. 2000;51(1):407-421. https://doi.org/10.1146/annurev.med.51.1.407

2. Ferkol T, Schraufnagel D. The global burden of respiratory disease. Ann Am Thorac Soc. 2014;11(3):404-406. https://doi.org/10.1513/AnnalsATS.201311-405PS

3. Graham N. The epidemiology of acute respiratory infections in children and adults: A global perspective. Epidemiol Rev. 1990;12(1):149-178. https://doi. org/10.1093/oxfordjournals.epirev.a036050

4. Pattemore P, Jennings L. Epidemiology of respiratory infections. In: Taussig L, Landau L, editors. Pediatric respiratory medicine. 2 nd ed. Philadelphia: Mosby Elsevier; 2018; p. 435-452.

5. Ksiazek T, Erdman D, Goldsmith C, et al. A novel coronavirus associated with severe acute respiratory syndrome. N Engl J Med. 2003;348(20):1953-1966. https://doi.org/10.1056/NEJMoa030781

6. Su S, Gu M, Liu D, et al. Epidemiology, evolution, and pathogenesis of H7N9 influenza viruses in five epidemic waves since 2013 in China. Trends Microbiol. 2017;25(9):713-728. https://doi.org/10.1016/j.tim.2017.06.008

7. Lu $X$, Whitaker B, Sakthivel $S$, et al. Real-time reverse transcription-PCR assay panel for middle east respiratory syndrome coronavirus. J Clin Microbiol. 2013;52(1):67-75. https://doi.org/10.1128/JCM.02533-13

8. International Health Regulations (2005) [homepage on the Internet]. World Health Organization; 2018 [cited 2018 Dec 19]. Available from: http://www.who. int/ihr/publications/9789241580496/en/.

9. Action Packages | Detect 1 - National Laboratory System [homepage on the Internet]. GHS Agenda.org; 2018 [cited 2018 Dec 19]. Available from: https:// www.ghsagenda.org/packages/d1-national-laboratory-system.

10. Polansky L, Outin-Blenman S, Moen A. Improved global capacity for influenza surveillance. Emerg Infect Dis. 2016;22(6):993-1001. https://doi.org/10.3201/ eid2206.151521

11. Dare R, Fry A, Chittaganpitch M, Sawanpanyalert P, Olsen S, Erdman D. Human coronavirus infections in rural Thailand: A comprehensive study using real-time reverse-transcription polymerase chain reaction assays. J Infect Dis. 2007;196(9):1321-1328. https://doi.org/10.1086/521308

12. Fry $A$, Chittaganpitch $M$, Baggett $H$, et al. The burden of hospitalized lower respiratory tract infection due to respiratory syncytial virus in rural Thailand. PLoS ONE. 2010;5(11):e15098. https://doi.org/10.1371/journal.pone.0015098

13. Heim A, Ebnet C, Harste G, Pring-Åkerblom P. Rapid and quantitative detection of human adenovirus DNA by real-time PCR. J Med Virol. 2003;70(2):228-239. https://doi.org/10.1002/jmv.10382

14. Lu X, Holloway B, Dare $R$, et al. Real-time reverse transcription-PCR assay for comprehensive detection of human rhinoviruses. J Clin Microbiol. 2007;46(2): 533-539. https://doi.org/10.1128/JCM.01739-07

15. Morgan $\mathrm{O}$, Chittaganpitch $\mathrm{M}$, Clague $\mathrm{B}$, et al. Hospitalization due to human parainfluenza virus-associated lower respiratory tract illness in rural Thailand. parainfluenza virus-associated lower respiratory tract illness in rural Thailand.
Influenza Other Respir Viruses. 2012;7(3):280-285. https://doi.org/10.1111/ j.1750-2659.2012.00393.x

16. Weinberg G, Schnabel K, Erdman D, et al. Field evaluation of TaqMan Array Card (TAC) for the simultaneous detection of multiple respiratory viruses in children with acute respiratory infection. J Clin Virol. 2013;57(3):254-260. https://doi. with acute respiratory infection.
org/10.1016/j.jcv.2013.03.016

17. Sakthivel S, Whitaker B, LuX, et al. Comparison of fast-track diagnostics respiratory pathogens multiplex real-time RT-PCR assay with in-house singleplex assays for pathogens multiplex real-time RT-PCR assay with in-house singleplex assays for 2012;185(2):259-266. https://doi.org/10.1016/j.jviromet.2012.07.010

18. Joint External Evaluation tool (JEE tool) - second edition [homepage on the Internet]. World Health Organization; 2018 [cited 2018 Dec 19]. Available from: https://www.who.int/ihr/publications/WHO HSE GCR 2018_2/en/. 